\title{
Autentisk beretning om et varslet selvmord
}

Ved Ingar Sletten Kolloen

Portrett av Tor Jonsson tegnet av Randi M onsen i A rbeiderbladet (1950)

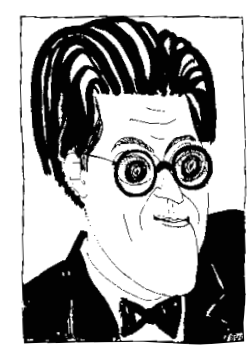

Mange har spurt hva som har gjort mest inntrykk på meg under det fire år lange arbeidet med biografien om dikteren Tor Jonsson, Berre kjaerleik og død (Samlaget 1999). Svaret er en dypere forståelse av hvilken kolossal kraft som finnes i hvert enkelt menneskes lengsel mot noe eller noen, men også hvilken sterk motkraft angsten for ikke å få lengselen oppfylt representerer, og hvordan denne utløser aggresjon, frykt, hat og andre negative følelser, som på et eller annet tidspunkt vil slå innover, i et livstruende selvhat.

$M$ ed den ene foten på gasspedalen og den andre på bremsepedalen kan resultatet bli at motoren går for full speed, men man opplever at man ikke kommer av flekken. Det trengs verken medisinsk eller psykologisk utdannelse for å skjønne at slikt blir man ikke bare fortvilet av, men syk. A lvorlig syk, ja, så syk at man kan drepe seg selv.

M in oppgave som biograf har vært å rekonstruere et liv så sannferdig som overhodet mulig, i dette tilfellet livet til en selvmorder. D erfor har jeg måttet arbeide som en politimann, et mord skulle jo oppklares. Jeg har avhørt godt og vel 150 mennesker om Tor Jonsson (1916-51). De fleste kjente ham personlig.

$M$ en det viktigste materialet jeg har hatt til rådighet under drapsetterforskningen, har vært Tor Jonssons egne brev, artikler, dikt, noveller, prosafragmenter, dramatikk og annet skriftlig materiale fra hans hånd. Betydelige deler av dette material et har jeg i faser av arbeidet nærmest hatt et pasientjournal-forhold til. Fordi det forteller så mye om hans lengsel mot livet, døden og kjærligheten, og angsten for ikke å få det oppfylt.

$\mathrm{H}$ ans diktning, som er sjeldent dypt rotfestet i eget liv, ble til i nettopp dette spenningsfeltet. Derfor kan hans diktning - og dermed min biografi - langt på veg leses og forstås som en autentisk beretning om et varslet selvmord. I prosautvalget som jeg har redigert, B lant bygdedyr og vestkantkrokodiller (Samlaget 2000), kommer dette tydelig til uttrykk.

\section{Barnesoldat i hellig krig}

Tor Jonsson var utlært barnesoldat lenge før han var konfirmert. $\mathrm{H}$ jemmet i Lom i G udbrandsdalen var hovedkvarteret $\mathrm{i}$ en mangeårig bygdekrig. H erfra førte faren en nådeløs kamp mot kristenfolk, ættebønder og andre autoritets- og myndighetspersoner i bygda. $\mathrm{N}$ ykonfirmerte Johannes J ohnsen, hans far, reiste ut av bygda som en hundset, slektløs legdunge rundt 1880. $\mathrm{N}$ ærmere 30 år senere vendte han tilbake med en drøm om å bli til noe i hjembygda; nemlig eier og driver av egen jord og etablerer av egen bondefamilie.

I egne - og sønnens - øyne kjempet Johannes Johnsen en hellig krig. For slik han så det hadde hans fiender, med bygdas prest i front, med ulovlige midler tvunget ham og hansfamilie ut av Paradis: bruket han hadde leid i ni år, og som han hadde vært så nær så nær å overta. H an sloss videre også etter at de var blitt tvunget til å flytte til en jordløs stugu.

Da sønnen var nesten 13 år gammel, vant faren en avgjørende rettssak. $\mathrm{H}$ an dro hjem og fortal te sine nærmeste og alle sambygdinger som gadd høre på ham, at nå ville rettferdigheten seire. De som hadde gjort ham urett ville få sin straff, og han og familien ville få tilbake det som urettmessig var tatt fra dem. Striden hadde vart i ti år. Slik Iærte Tor Jonsson verdien av å kjempe.

\section{Den svarte skuggen}

Da Johannes Johnsen ble senket i jorden, ble også sønnens drømmer om å vende tilbake til Paradis begravd. Dermed begynte Tor Jonsson for alvor å dyrke sitt etter hvert legendariske svartsyn: De skjebnegudene som ikke vil deg vel tar alltid siste stikk, din gode vilje kommer til kort. Barnetroen hadde faren for lengst plukket av ham.

M en det faren hadde lært ham om klassesamfunnets overgripere og ofre, ble ikke begravd. $\mathrm{H}$ an overtok og videreutviklet med stor iver og dyktighet alle farens fiendebilder. Slik lærte Tor Jonsson å nære hatet, farsarven sin. Det onde hadde kommet inn i hans verden, med katastrofale konsekvenser, for det infiserte også han, skulle han finne ut mange år senere, da han skrev om en skugge. "D enne skuggen kjende eg i meg. M idt i gladaste leiken hende det at eg tok spranget bort i skogskuggen. A It ikring meg var sol, blomar og blå himmel. M en sjølv var eg svart. Eg var vond - Eg var full av svarte rop. G jer noko gale og gråt! - G røtte eg dei andre borna, låg sorga i meg som ei svart glede og gjorde meg stor og sterk, " skriver han helt på slutten av sitt liv.

I sluttoppgjøret anvendte han stadig nøkkelbegreper som "herleg sorg" og "svart glede".

\section{Sosial fobi}

A llerede før Johannes Johnsen døde, begynte hans hustru å stenge seg inne i eget sinn med sin skam og maktesl øshet.

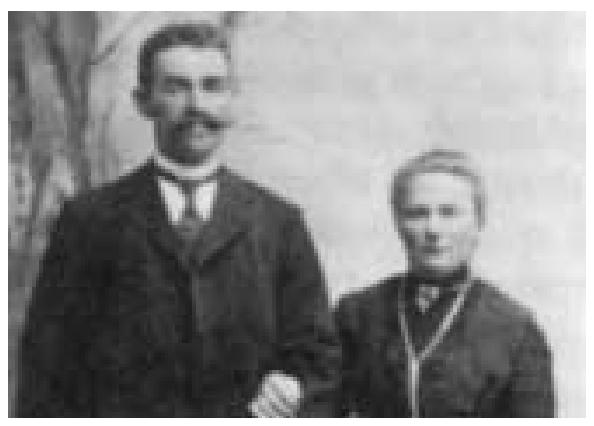

Tor Jonssons foreldre, Johannes og Torø

Selv sine to søstre, som bodde innen en omkrets av 200 meter, sluttet hun nærmest å oppsøke. Slik fikk Tor Jonsson tidlig smake på morsarven, en isolasjonstrang som han etter hvert utviklet til sosial fobi. Fattigdommens ektefødte barn, mindreverdighetsfølelsen, hadde han for lengst sittende tungt på skuldrene. $\mathrm{H}$ an ble en innevinner, dyktig i skolen som han var, men en utetaper, som kom til kort, med dårlig syn og kroppsbeherskelse. Det hjalp lite å kunne kongerekkene på rams, når han verken kunne slå stikkballer, klatre høyt i trærne eller renne raskt på ski. $H$ an ble en sinke som ikke engang innkasserte trøstepokaler i disse så viktige disiplinene i en vilter gutteflokk.

I perioder av oppveksten fikk han et par nære venner, som delte hans voldsomme lesehunger og trang til å fantasere. $M$ en da disse ville inn i virkeligheten igjen, enten det var lek eller andre aktiviteter som lokket mer, ble han sjelden med, fornærmet som han var over at hans fortrolige kunne velge de andre, flokken, framfor ham. 


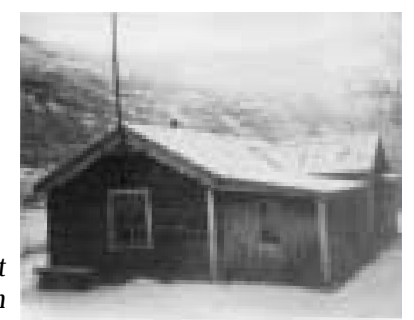

\section{Selvmord som løsning}

O g nettopp den enkelte mot flokken kom til å bli et yndet litterært studieobjekt for Tor Jonsson i årene framover. Et drøyt tiår etter at A ksel Sandemose målbar småborgerskapets Jantel over, satte Tor Jonsson ord på en annen nært beslektet flokkmental itet; bygdedyret. Dette glefser i seg alle som skiller seg ut og ikke aksepterer sin ættefødde plass i bygdesamfunnet.

$\mathrm{Da}$ han debuterte bare 16 år gammel med en novelle i A rbeidermagasinet, var møtet med disse destruktive mekanismene hovedtemaet. Tor Jonsson lot hovedpersonen, som hadde svært mange likhetstrekk med sin opphavsmann, velge selvmordet som løsning på sine problemer. Det første av en rekke selvmord blant hans liden de litterære personer.

$H$ an skildret fra første stund sel vmorderdøden i svært så lyse farger, som i debutteksten, E it illmenne:

" $H$ an såg ned $i$ vatnet. D en myrke tjørni spegla av den ljose himmelen, der strålane leika med ovven glans. $H$ an såg upp på himmelen. $\mathrm{H}$ uldrelandet strøymde imot han og inn i sjeli og lyfte han upp. E itt såg han: D et fagre."

\section{Den svarte skuggen på ny}

A tten år, tre lyrikkbøker og en artikkelsamling senere vendte Tor Jonsson ryggen til livet. $\mathrm{H}$ an var kommet fram til at døden hadde mer å by på enn livet. $\mathrm{H}$ an var blitt konfrontert med hatet i seg, først i møtet med den synske

$\mathrm{M}$ arcello $\mathrm{H}$ augen, og dernest i møtet med en kvinne han hadde håpet kunne omskape ham med sin kjærlighet. $M$ en det kunne hun ikke, og det var hans skyld, mente han og utstedte denne dommen: "E g elskar ikkje sorga i augo hennar lenger. A ttanfor sorga ser eg berre denne svarte skuggen, som krøkjer armane omkring henne, held henne fast så ho aldri, aldri kan koma meg i møte. - Skuggen som held henne fast er skuggen av min eigen fattigdom. $M$ itt grenselaust fattige liv." $\mathrm{H}$ an hadde plassert seg selv på analysebenken, men uten terapeut. Som vanlig var Tor Jonsson helt al ene. Der fant han en indre fattigdom, en sjelelig krøplingtilstand. Det hadde gått fattigdom, mindreverdighetsfølelse, hat mot andre og til slutt hat mot ham selv i alt.

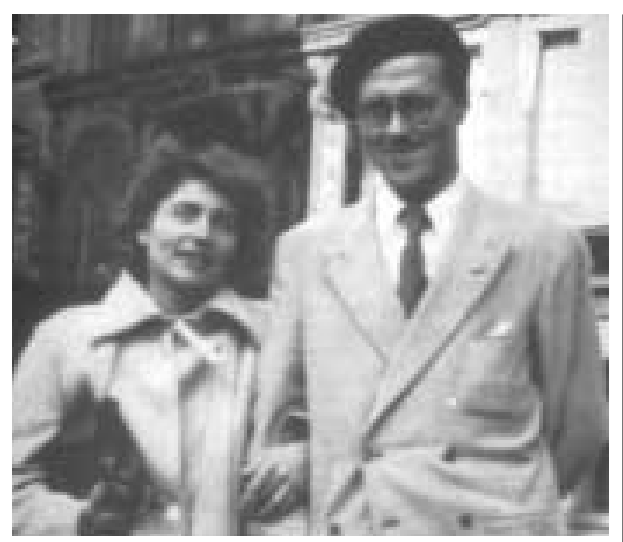

Tor Jonsson og Ruth A Ivesen i 0 slo høsten 1950

\section{Farlig lengsel}

Tor Jonsson bar gjennom hele sitt liv og sin diktning på de lengslene vi alle bærer i oss med vekslende styrke i ulike faser av livet: den politiske lengselen etter et mer rettferdig samfunn, den humanistiske lengselen etter et varmere liv rundt oss og den eksistensielle lengselen etter en partner å forene seg med for å skape nytt liv.

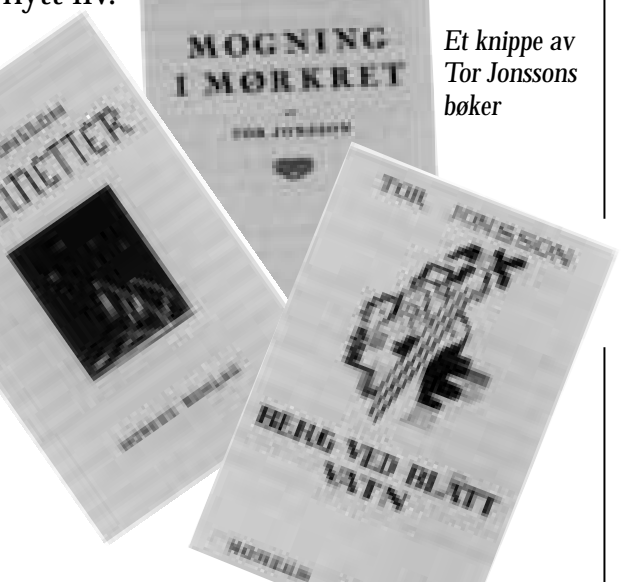

På vegne av alle andre var han optimist

til det siste. $M$ en når det gjaldt ham selv og hans mulighet til å få tilfredsstilt sine lengsler, tror jeg han var pessimist fra det tidspunkt faren døde fra ham. Lenge skyldte han på alle andre. Til slutt la han skylden utelukkende på seg selv. Til mer skyld, til tyngre bør. $0 \mathrm{~g}$ til større ytre suksess i ordlivet, til sterkere opplevde han sitt virkelige liv som fullstendig mislykket.

$H$ an så den eneste mulige redning $i$ den omskapende kvinnekjærligheten. Da dette heller ikke var mulig, fordi han opplevde seg selv som ødelagt, ven dte han ryggen til livet. Døden hadde mer å by på enn livet. For på den andre sida ventet moren på ham. M ed henne kunne han forene seg og slik skape seg helt om, til "atterføding or ny grunn". Dermed endte han opp med å se selvmorderdøden som en ny fødsel.

Dette i sannhet beksvarte og fundamentalt livsfien dtlige evangeliet hadde nok Tor Jonsson bekjent seg til i mange år. $\mathrm{N}$ år han helt i sluttstriden skriver diktet "Fattig ynskje", tar han konsekvensen av sin mørke tro:
"Var eg ein G ud
ville eg skapa
ei stillare verd.
D er skulle alle elske.
Var eg ein G ud,
ville eg skapa
kjærleik og død,
berre kjærleik og død."

Den desperate lengselen drev Tor Jonsson framover, angsten for ikke å nå fram holdt ham tilbake. Derfor tok han snarvegen ved å gjøre seg til $\mathrm{G}$ ud - med fatalt resultat.

$0 \mathrm{~g}$ derfor blir det ikke bare patetisk, men også direkte uanstendig når selvmorderdøden til Tor Jonsson og andre kunstnere blir heroisert og romantisert.

U levd virkelig liv kan aldri erstattes av levd dikterliv.
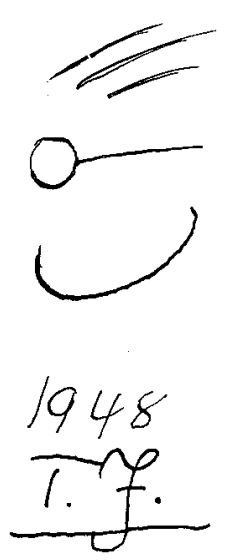

Selvportrett

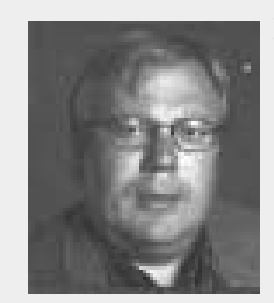
Ingar Sletten Kolloen, født i 1951, publiserte i 1999 en sterkt kritikerrost biografi om dikteren Tor Jonsson, Berre kjærleik og død. Boken ble en publikumssuksess, foreløpig solgt i 10.000 eksemplarer. 4. opplag er nå under forberedelse. I februar i år utkom B lant bygdedyr og vestkantkrokodiller, et utvalg av Tor Jonssons prosa, som Kolloen har redigert. Ingar Sletten Kolloen har allsidig erfaring fra presse og kulturliv.

Bildene i artikkelen er fra boka Berre kjærleik og død. 